\title{
Anatomical study of the renal veins observed during 342 living-donor nephrectomies
}

\author{
BAP-Centro Hospitalar Dom Silvério Gomes Pimenta, Universidade Federal de São Paulo - São Paulo, Brazil
}

The anatomical variations of renal veins observed during 342 nephrectomies in living donors are described, 311 cases on the left side and 31 on the right. The following anatomy of the renocava veins was observed: 1 . On the left side the renal vein was always unique $(311 / 311)$ and had two tributaries (suprarenal and gonadal veins) in 100 per cent and one or more renolumbar veins in 65.27 per cent, encircling the aorta in 1.07 per cent, was retroaortic in 1.4 per cent; and the inferior vena cava was double in 0.64 per cent; B- on the right side the renal vein was double in 29 per cent (9/31) and had only one tributary (gonadal vein) in one case, for 3.22 per cent (1/ $31)$; three or more renal veins in 9.7 per cent $(3 / 31)$. We concluded that the left renal vein is always unique, presenting variations principally in its tributaries and trajectory. On the right side, the renal vein was double or triple in 38.79 per cent

UNITERMS: Nephrectomies. Renal veins. Kidney transplantation.

\section{INTRODUCTION}

I $t$ is crucial to know the anatomy of the renal vessels during a retroperitoneal approach to prevent bleeding by accidental tearing.' Comparably, the renal venous pattern of the right side bears little resemblance to that of the left. In its relatively short course from the kidney to the inferior vena cava, the right vein rarely receives a tributary. The longer left renal vein (LRV), on the contrary, regularly receives the following tributaries: suprarenal and inferior phrenic, from above, frequently joined; gonadal (testicular or ovarian) from below; and renolumbar vein posteriorly, often by a confluent with the gonadal vein. ${ }^{2.3}$

\author{
Address for correspondence: \\ José Carlos Costa Baptista-Silva \\ Rua Prof. Artur Ramos, 178, 123-Vega \\ São Paulo/SP - Brasil - CEP 01454-904
}

During the living donor nephrectomy, the left kidney is used more often as a donor organ because its vein is longer than the right renal vein. Usually, the LRV anteriorly crosses the aorta before reaching the vena cava. ${ }^{4}$ Our objective was to show the anatomical variations of the renal veins observed in 342 living donor nephrectomies.

\section{MATERIAL AND METHODS}

From May 1990 to May 1996, 342 living-donor nephretomies (311 on the left side and 31 on the right) were performed at Dom Silvério Gomes Pimenta (260) and Beneficência Portuguesa (82) Hospitals. Of the 342, 208 cases were female and 134 male, 85 per cent were white, and the average age was 43.8 years. All cases were studied through preoperative renal angiography and intraoperative observation. ${ }^{5}$ 


\section{Left Side}

In 311 cases submitted to the left nephrectomy, we found that:

A. $203(65.27$ per cent $)$ left renal veins always had three tributaries, these being the suprarenal vein superiorly, the gonadal vein (testicular or ovarian veins) inferiorly, and one or more renolumbar veins; two cases circumaortic venous ring, and that;

B. 108 (34.72 per cent) left renal veins had only two tributaries, a suprarenal and a gonadal vein [four cases of retroaortic renal vein, one case of circumaortic venous ring, and two of duplication inferior vena cava (DIVC)](Table 1, Fig.1).

\section{Right side}

In 31 cases submitted to a right nephrectomy, we found that:

A. 19 (61.29 per cent $)$ cases had only one renal vein;

B. 9 (29 per cent) had two renal veins (one case had a gonadal tributary), and that;

C. 3 (9.7 per cent) cases had three or more renal veins (Table 1, Fig. 2).

\section{DISCUSSION}

We found that the left renal vein always had two tributaries, the suprarenal vein superiorly and a gonadal vein (testicular or ovarian veins) inferiorly in 100 per cent, and usually one or more renolumbar veins in 65.27 per cent. Lejars $^{6}$ found one or more renolumbar veins of LRV in 88 per cent, Yang et al. ${ }^{7}$ in 60.8 per cent, Cooley \& Wukasch' in 95 per cent and Pinto ${ }^{8}$ in 63.36 per cent of the cases.

On the right side, we found just one tributary only once, the gonadal in 3.22 per cent, while Anson \& Kurth, ${ }^{9}$ Anson \& Daseler ${ }^{4}$ found it in 10-20 per cent, and Pinto ${ }^{8}$ in 10.89 per cent.

Cooley \& Wukasch' have said that in aortic abdominal disease, trauma of the renal vessels of the left side, it is very important to do the ligation and section of the renolumbar, testicular and suprarenal veins in a

\section{Table 1}

Results of $\mathbf{3 4 2}$ living-donor nephretomies showing the variations of the renal veins and their tributaries.

Veins

Right side Left side

One renal vein

Two renal veins 09

Three or more renal veins

19

311

0

03

0

Tributaries $\angle \begin{aligned} & \text { one }(\mathrm{G}) \\ & \text { two }(\mathrm{G}+\mathrm{S}) \\ & \text { three or more } \\ & (\mathrm{G}+\mathrm{S}+\mathrm{RI})\end{aligned}$

01

0

108

203

RLRV

$\mathrm{Ca}$

DIVC

04

03

02

$(\mathrm{G}=$ gonadal vein, $\mathrm{S}=$ suprarenal vein, $\mathrm{RI}=$ renolumbar vein, DIVC = duplication of the inferior vena cava, RLRV =retroaortic left renal vein, $\mathrm{Ca}=$ circumaortic venous ring)

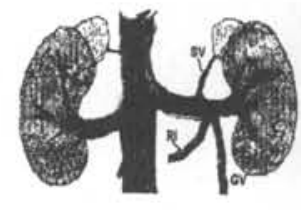

a

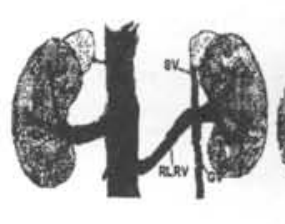

d

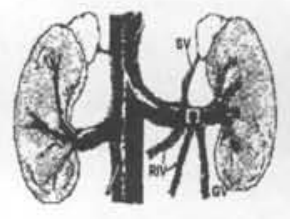

b

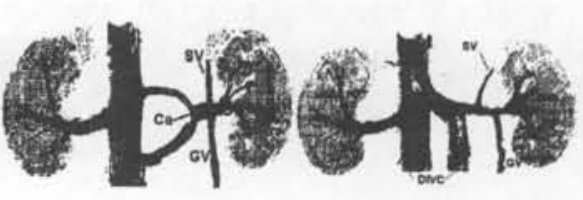

e

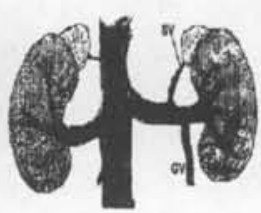

c f
FIGURE 1 - Nephrectomy on left side showing the veins encountered: a- one renolumbar (R1), b- two renolumbars (R1), c- only suprarenal and gonadal (SV, GV), d- retroaortic (RLRV), e- circumaortic ring (Ca), f- double cava infrarenal (DIVC).

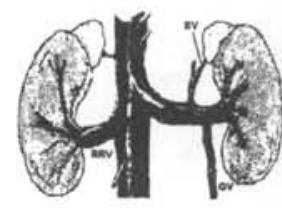

a

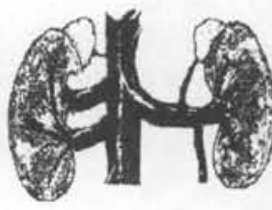

b

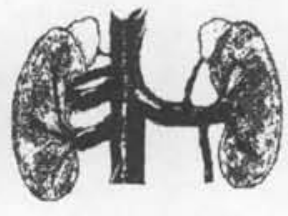

C
FIGURE 2 - Nephrectomy on right side showing the veins encountered: a- one renal vein, b- two renal veins, c- three renal veins. 
cephalad direction for better mobilization of the left renal vein. By increasing the mobility of the left vein and the inferior cava, this maneuver provides excellent exposure of the both renal arteries and precludes the necessity of transecting the left renal vein.

We observed that the renolumbar vein vessels on the left side may be single or multiple, and that they had many variations in their width and local that reach the left renal vein. Usually, they reached the LRV close to the gonadal vein, as was found by Anson \& Kurth, ${ }^{9}$ Anson \& Daseler, ${ }^{4}$ and Pinto. ${ }^{8}$

In our research, on the left side we observed the LRV was always unique, retroaortic in 1.28 per cent, circumaortic venous ring in 0.96 per cent; and a duplication of the inferior vena cava in 0.64 per cent. Lattore ${ }^{10}$ observed that the LRV is retroaortic in 1-3.4 per cent, circumaortic in 6-8.7 per cent and that the inferior vena cava is double from 1-3 per cent. Pinto ${ }^{8}$ found that the LRV is retroaortic in 1.98 per cent, circumaortic in 1.98 per cent, and the inferior vena cava double in 0.99 per cent.

On the right side, we found a double renal vein in 29 per cent, and triple or more in 9.7 per cent of the 31 nephretomies, but Anson et al. ${ }^{2}$ said that the right vein is occasionally double and rarely tripled, and is uncommonly the recipient of tributaries. Pinto ${ }^{8}$ found a double right renal vein in 22.77 per cent.

We observed that when the angiography showed more than one renal artery, it was more common to find two or more renal veins on the right side during surgery. ${ }^{3.5}$ It is clear that when the left renal vein curves inferior in preoperative angiography, it strongly suggests that it courses retroaortic. ${ }^{3,7}$ This confirms the importance of a complete preoperative angiography (arterio- and venographific phases) to decide which kidney should be removed. ${ }^{3.5}$ When either kidney is demonstrated to be satisfactory, the left is usually chosen because the longer renal vein contributes to the technical ease of the nephrectomy and subsequent transplant.

These anatomical variations of the renocava veins must be kept in mind to prevent bleeding by an accidental lesion when operating in the retroperitoneal region.

\section{CONCLUSION}

We concluded that the renal veins were:

1. Always unique on the left $\operatorname{side}(311 / 311)$ and longer, and always had two tributaries (suprarenal and gonadal veins), and one or more renolumbar veins in 65.27 per cent (203/311), encircled the aorta (circumaorta venous ring) in 1.07 per cent (3/311), and were retroaortic in 1.4 per cent (4/311); and double cava in 0.64 per cent $(2 / 331)$.

2. Double on the right side in 29 per cent (9/310), and had only one tributary (gonadal vein) in one case, for 3.22 per cent (1/31); and three or more renal veins in 9.7 per cent $(3 / 31)$.

\section{Resumo}

Objetivo: é demonstrar as variações anatômicas das veias renais encontradas em 342 nefrectomias realizadas em doadoresvivos. Material e Método: de maio de 1990 a maio de 1996 realizamos 342 nefrectomias em doadores-vivos para transplante sendo 331 à esquerda e 31 à direita Resultados: encontramos a seguinte anatomia das veias renais: no lado esquerdo a veia renal era sempre única ( $311 / 311$ ), tinha duas tributárias (veias suprarenal e gonadal) em $100 \%$ e uma ou mais veias renolumbares em $65,27 \%$, circundava a aorta (circumaorta venous ring) em $0,96 \%$ e era retroaortica em $1,28 \%$, cava dupla $0.64 \%$; no lado direito a veia renal era dupla em $29 \%(9 / 31)$ e somente uma vez $(3,22 \%)$ tinha uma veia tributária (veia gonadal), três ou mais veias em $9,7 \%$. Conclusão: a veia renal esquerda é sempre única, apresenta variação principalmente no seu trajeto e em suas tributárias, enquanto a veia renal direita é dupla ou tripla em $38,7 \%$. 


\section{REFERENCES}

1. Cooley DA, Wukasch DC, eds. Techniques in vascular surgery. Philadelphia: Saunders, 1978:282.

2. Anson BJ, Cauldwell EW, Pick JW, Beaton LE. The anatomy of the pararenal system of veins, with comments on the renal arteries. J Urol 1948;60:714-37.

3. Baptista-Silva JCC, Cal RGR, Castro MJ, Veríssimo MJM, Câmara ALG. Estudo anatômico das veias renais e suas variações, observação durante as nefrectomias em doadoresvivos. Rev Col Bras Cir 1995;22(2): 18.

4. Anson BJ, Daseler EH. Common variations in the renal blood supply. Surg Gynecol Obstet 1961;112:439-49.

5. Baptista-Silva JCC, Figeiredo LFP, Cal RGR, Castro MJ, Veríssimo MJM, Câmara ALG. Importância da angiografia na seleção do doador-vivo renal. J Bras Urol 1995;21(4):244.

6. Lejars F. Les voies de surete de la veine renale. Bull Soc Anat (Paris) 1888;63:504-11.

7. Yang SC, Suh DH, Kim YS, Park K. Anatomical study of the left renal vein and its draining veins, as found during living donor nephrectomy. Transplant Proc 1992;24(4):1333-4.

8. Pinto MG. Variações anatômicas venosas renocava encontradas em 101 cadáveres. (Mestrado Thesis). São Paulo, UNIVERSIDADE FEDERAL DE SÃO PAULO/ EPM, 1996:104.

9. Anson BJ, Kurth LE. Common variations in the renal anatomy affecting blood supply. Surg Gynecol Obstet 1955;100:157-60.

10. Lattore J. Malformaciones congénitas. In Villalonga JT, ed. Sector iliocava. Barcelona: Uriach, 1993:70-112. 